\title{
Penyuluhan Pelatihan Kepemimpinan Kepada Karang Taruna Desa Grabagan Sidohajo Kec.Susukan Kab.Semarang
}

\author{
${ }^{1}$ Mustaan ${ }^{*},{ }^{2}$ Dian Muhammad Rifai, ${ }^{3}$ Ahwan, ${ }^{4}$ Anik Suwarni \\ Universitas Sahid Surakarta/Program Studi IImu Komunikasi ${ }^{1}$ \\ Universitas Sahid Surakarta/Program Studi Desain Interior ${ }^{2}$ \\ Universitas Sahid Surakarta/Program Studi IImu Farmasi ${ }^{3}$ \\ Universitas Sahid Surakarta/Program Studi Keperawatan ${ }^{4}$ \\ e-mail: mustaan57@gmail.com ${ }^{1}$, dianrifai344@gmail.com ${ }^{2}$, \\ ahone.far02@gmail.com ${ }^{3}$, aniksw2006@gmail.com ${ }^{4}$ \\ *Coresponding Author
}

Submited: Sept 19, 2021; Revised: Sept 29, 2021; Accepted: Oct 22, 2021; Published: October 30,2021

\begin{abstract}
Abstrak
Kepemimpinan merupakan kunci sukses untuk meningkatkan kemajuan suatu sumber daya manusia (SDM) di suatu daerah. Kepemimpinan tidak hanya diperoleh dari bakat atau karismatik tetapi dapat diperoleh dengan adanya pelatihan kepemimpinan itu sendiri. Kepemimpinan dalam pengabdian ini digunakan untuk menumbuhkan jiwa pemimpin pada genaerasi muda yang ada dipedesaan melalui wadah karang taruna di desa Grabagan Sidoharjo Kecamatan Susukan Kab. Semarang. Metode yang digunakan adalah memberikan materi kepemimpinan kepada peserta karang taruna, diskusi dan melatih membangun kepribadian kepemimpinan, keorganisasian, memahami peran, tujuan dan fungsi organisasi dan sikap peduli terhadap lingkungan masyarakat. Hasil pengabdian pelatihan dasar kepemimpinan yang dilakukan oleh tim pengabdian dapat memberikan ilmu yang bermanfaat bagi peserta karang taruna yang mengikuti pelatihan ini. Peserta yang mengikuti ini sangat antusias dan aktif dalam melaksanakan pelatihan ini. Sehingga hasil yang didapatkan melalui latihan dasar kepemimpinan menjadi lebih bermanfaat bagi para peserta sehingga dapat di aplikasikan generasi muda karang taruna dalam membangun Desa Grabagan Sidoharjo Kecamatan Susukan Kabupaten Semarang dengan berbagai macam program kerja.
\end{abstract}

Kata kunci : Kepemimpinan, Desa Grabagan Sidoharjo, Latihan Dasar Kepemimpinan (LDK)

\section{Abstract}

Leadership is the key to success in increasing the progress of human resources $(H R)$ in an area. Leadership is not only obtained from talent or charismatic but can be obtained by the leadership training itself. Leadership in this service is used to foster the spirit of leadership in the young generation in rural areas through youth 
organizations in Grabagan village, Sidoharjo, Susukan District, Kab. Semarang. The method used is to provide leadership material to youth organizations, discuss and train to build leadership personality, organization, understand the role, goals and functions of the organization and care about the community environment. The results of the basic leadership training service carried out by the service team can provide useful knowledge for youth participants who take part in this training. The participants who took part were very enthusiastic and active in carrying out this training. So that the results obtained through basic leadership training become more useful for the participants so that they can be applied to the younger generation of youth organizations in building Grabagan Village, Sidoharjo, Susukan District, Semarang Regency with various work programs.

Keywords: Leadership, Grabagan Village Sidoharjo, Basic Leadership Training (LDK)

This is an open access article under the CC BY-SA license.

\section{PENDAHULUAN}

Kepemimpinan adalah kewibawaan yang dapat mempengaruhi dan menggerakan orang, baik secara perseorangan atau kelompok di suatu organisasi, sehingga menimbulkan kemampuan untuk melakukan dan mempengaruhi untuk mencapai tujuan suatu organisasi. Kepemimpinan dalam berbagai dimensi, dan mempunyai fungsi sebagai piranti penggerak, motor atau motivator sumber daya manusia disuatu organisasi, sehingga kepemimpinan diharapkan dapat menggerakan organisasi dalam mencapai tujuan (Fitriani, 2017).

Kepemimpinan generasi muda dibutuhkan karena generasi muda adalah penerus bangsa kedepannya, bangsa ini akan bisa berkembang dengan nilai - nilai pancasila dengan adanya generasi muda yang mempunyai karakter nasionalis dan agamis. Karakter ini dapat terbentuk apabila kepemimpinan generasi muda terbentuk sejak dini, sehingga pembentukan karakter pemuda dapat terwujud dalam pembangunan bangsa indonesia kedepan (Ambarita, 2013).

Pembinaan generasi muda yang kritis, aktif, humanis, familier, dan berakhlakul karimah, merupakan bagian fundamental dari tujuan dan cita-cita para pemerhati tunas bangsa baik secara personal maupun komunal. Mereka secara bersama-sama mengkonstrasikan orientasi pembinaan melalui institusi formal, informal, maupun pembelajaran organisasi dan manajemen yang terbentuk dalam sebuah siklus organisasi, Badan, Lembaga maupun persatuan terutama dalam kegiatan Latihan Dasar Kepemiminan (LDK) (Azizy, 2000). Oleh karena itu, seiring dengan berkembang pesatnya era Globalisasi, maka sangatalah perlu untuk diadakan kegiatan khususnya sebagai bentuk refleksi bahkan penanaman sosial bagi generasi muda dewasa masa kini yang dalam hal ini khususnya Karang Taruna (Ambarwati \& Raharjo, 2018).

Organisasi Karang Taruna merupakan wadah yang mewadahi aktifitas generasi muda di tingkat desa bahkan Rukun Warga atau dukuh. Karang taruna merupakan dasar pembinaan karakter yang tepat dalam meningkatkan jiwa kepemimpinan genarasi muda mulai tingkat bawah, sehingga diperoleh bibit-bibit genarasi muda yang berkualitas secara sosial dan agama (Mulyadi, 
Sutrisno, Paeno, Harjianto, \& Winata, 2020). Peningkatan kepemimpinan yang baik akan berimbas kepada pembanguna desa atau daerah yang ada, dengan adanya program-program yang mempunyai inovasi yang akhirnya dapat dinikmati masyarakat desa (Seftyono, Arumsari, Arditama, \& Lutfi, 2016).

Dalam kepengurusan Karang Taruna mempunyai fungsi jalur pembinaan genarasi muda dalam mewujudkan fungsi dan tugasnya, kemauan dan kemampuan kepemimpinan Karang Taruna dapat berperan dengan sebaiknya secara teratur, terencana dan berkesinambungan dilaksanakan pembinaan dan pengembangan bagi para pelaku kepemimpinan tersebut (Bintari \& Darmawan, 2016).

Hal diatas tersebut membuat peneliti ingin membuat suatu pelatihan kepemimpinan dengan pelatihan Latihan Keterampilan Dasar (LDK) terhadap generasi muda Karang Taruna Desa Grabagan Sidoharjo Kecamatan Susukan Kabupaten Semarang Jawa tengah.

\section{METODE}

Pengabdian ini dilakukan dengan metode penyuluhan dan pemberian latihan dengan diskusi dengan memberikan materi Latihan Dasar Kepemimpinan (LDK) yang dilakukan oleh trainer dengan menggunakan game dan kuis. Dalam tahapan pelakasanaan pengabdian ini digunakan beberapa tahapan diantaranya:

\section{Observasi Tempat Pengabdian}

Penentuan tempat dilakukan didesa grabagan Sidoharjo Kecamatan Susukan Kabupaten Semarang dengan malakukan survei lokasi terlebih dahulu. Tempat pengabdian yang telah disurvei, lalu dilampirkan surat tugas untuk melakkan izin pengabdian di Karang Taruna Desa Grabagan Sidoharjo.

\section{Pelaksanaan Pengabdian}

Pengabdian masyarakat yang dilaksanakan diikuti oleh 50 peserta diaman peserta diberikan materi berupa kegiatan LatihanDasar Kepemimpinan (LDK) di sesuaikan dengan kebutuhan praktis dan bersifat aplikatif yang di tetapkan di lingkungan Desa Grabagan Sidoharjo, meliputi: membangun kepribadian kepemimpinan, keorganisasian, memahami peran, tujuan dan fungsi organisasi serta sikap peduli terhadap lingkungan masyarakat

\section{Evaluasi Hasil Pengabdian}

Tingkat keberhasilan pengabdian ini dengan melakukan evaluasi meliputi: a) Frekuensi kehadiran peserta pengabdian, dapat dilihat dari presensi kehadiran

b) Antusias atau minat peserta pegabdian cukup tinggi pada saat penyampaian materi.

\section{HASIL DAN PEMBAHASAN}

Pengabdian masyarakat ini dilakukan di Desa Grabagan Sidoharjo Kecamatan Susukan Kabupaten Semarang dengan tema pelatihan kepemimpinan kepada Peserta Karang Taruna Desa Grabagan Sidoharjo. Pengabdian ini dimaksudkan dengan tujuan untuk membangun potensi peserta agar menjadi manusia yang beriman dan bertakwa kepada Tuhan Yang Maha Esa, Berakhlak Mulia, Sehat, Berilmu, Cakap, Kreatif, Mandiri,dan menjadi warga negara yang 
demokratis serta bertanggung jawab; Meningkatkan pengetahuan, keterampilan serta kepribadian peserta sebagai calon pemimpin, dalam menjalankan tugas pokok dan fungsi kepemimpinannya dengan baik; Peserta LDK mempunyai kemampuan mengemukakan konsep dan gagasan serta dapat menerapkan demi kemajuan organisasi dengan menerapkan prinsip KIS (Koorganisasi, Integrasi, Keorganisasian); Peserta didik memiliki kecerdasan spiritual, intelektual dan emosional; Menumbuh kembangkan kepercayaan diri; Meningkatkan persatuan dan kesatuan dan memperoleh kader-kader Karang Taruna yang handal.

Media pengabdian yang digunakan yang pertama adalah sarasehan atau diskusi yang dialukan perkelompok peserta dengan materi kepemimpinan pada generasi muda karang taruna, sehingga peserta memahami dan dapat mengaktualisasi diri jiwa kepemimpinannya masingmasing pada gambar 1.

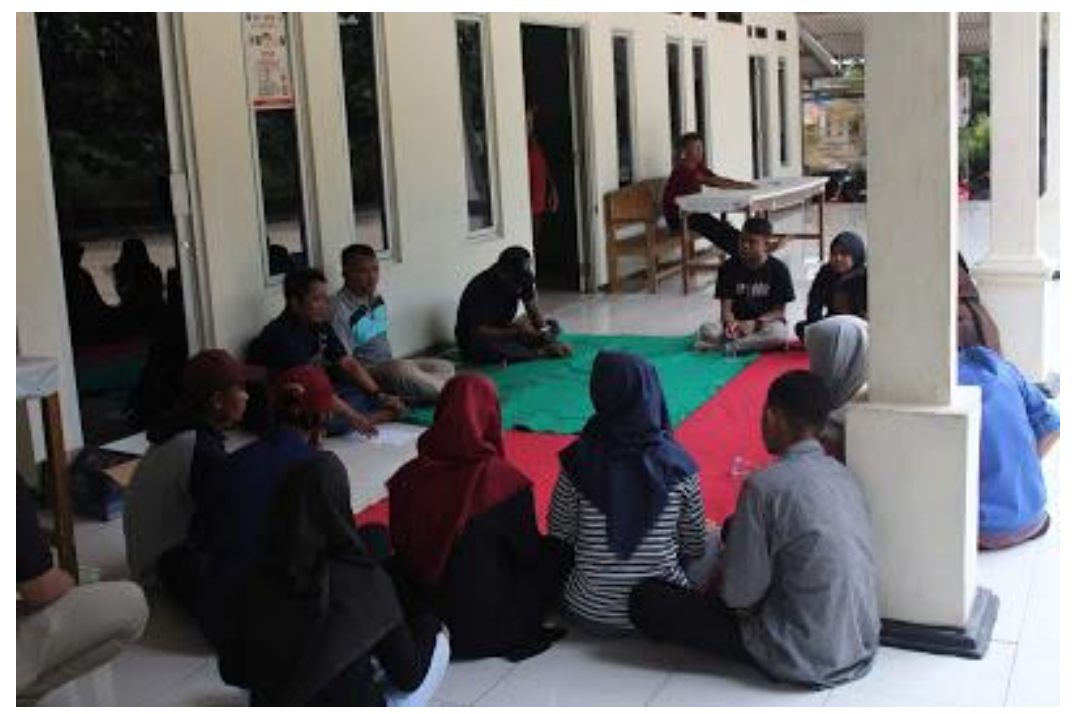

Gambar 1. Diskusi dan Saresahan Materi Latihan Dasar Kepemimpinan (LDK)

Materi pengabdian yang kedua berupa latihan kedisplinan dan bela negara berupa Latihan Baris berbaris, dimana latihan ini lakukan oleh trainer yang telah ditentukan oleh team pengabdian. latihan mempunyai fungsi dapat meningkatkan kedisiplinan dan cinta tanah air indonesia, sehingga semangat membangun dan memiliki bangsa indoensia dapat terwujud dengan nilai-nilai pancasila dan keagamaan yang terbentuk pada Gambar $\mathbf{2}$. 


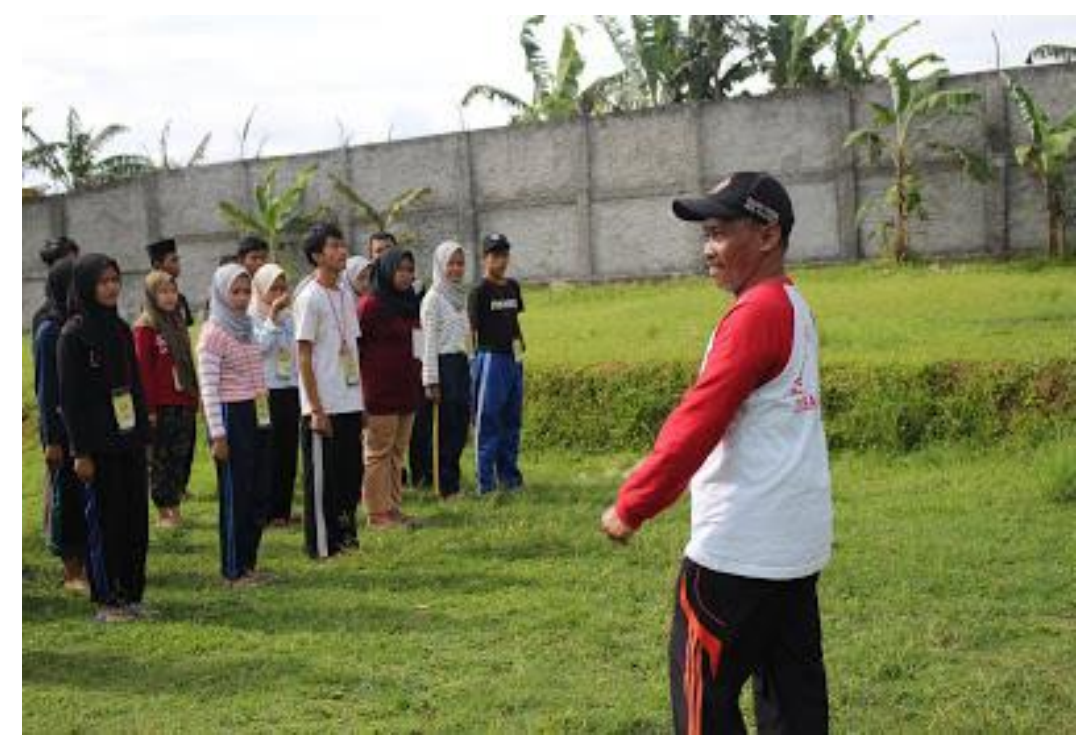

Gambar 2. Latihan Pasukan Baris - Berbaris

Pada Gambar 3 disampaikan materi ketiga berupa game atau permaianan yang dapat meningkatkan daya atau pola pikir peserta pelatihan kepemimpinan dalam bersosialisasi di masyarakat terutam di tingkat pedesaan, sehingga peserta menjadi makhluk sosial yang habluminallah dan habluminana, apabila bila kedua ini tercapai maka kepeminpinan yang diperoleh oleh generasi muda akan diperoleh secara optimal dan perkembangan Desa Grabagan Sidoharjo akan menjadi Desa yang Gema Ripah Loh Jinawi.
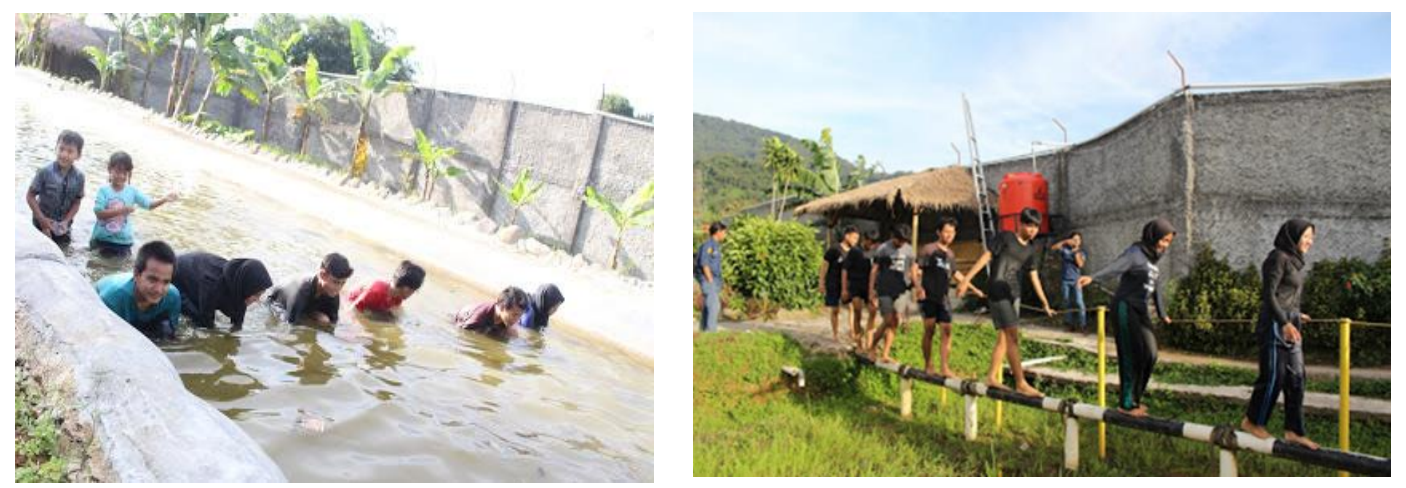

Gambar 3. Permainan Latihan Dasar Kepemimpinan (LDK)

\section{SIMPULAN}

Pengabdian ini memberikan manfaat yang sangat bagus dalam peningkatan Sumber daya Manusia (SDM) pada generasi Muda yaitu anggota Karang Taruna Desa Grabagan Sidoharjo Kecamatan Susukan Kabupaten Semarang. Hasil ini juga harus diimbangi dari program kerja desa yang mengarah kepada pembangunan generasi muda, sehingga generasi muda diikutsertakan dalam pembangunan desa seutuhkan. Kolaborasi ini akan saling dapat menguatkan desa menjadi desa yang tangguh dan kuat pada era globalisasi.

\section{DAFTAR REFERENSI}

Ambarita, B. (2013). Profesionalisme, Esensi Kepemimpinan, Dan Manajemen Organisasi.

Generasi KampuS, 6(2). 
Ambarwati, A., \& Raharjo, S. T. (2018). Prinsip Kepemimpinan Character Of A Leader Pada Era Generasi Milenial. PHILANTHROPY: Journal Of Psychology, 2(2), 114-127.

Azizy, A. Q. A. (2000). Islam dan Permasalahan Sosial. LKIS PELANGI AKSARA.

Bintari, P. N., \& Darmawan, C. (2016). Peran pemuda sebagai penerus tradisi sambatan dalam rangka pembentukan karakter gotong royong. Jurnal Pendidikan IImu Sosial, 25(1), 57-76.

Fitriani, F. (2017). Pelatihan Dasar Kepemimpinan (Ldk) Bagi Mahasiswa Fakultas IImu Sosial Dan IImu Politik Universitas Musamus. Societas: Jurnal IImu Administrasi dan Sosial, 6(1), 62-77.

Mulyadi, M., Sutrisno, S., Paeno, P., Harjianto, P., \& Winata, H. (2020). Penyuluhan Manajemen Sumber Daya Manusia Untuk Pengembangan Karang Taruna Mekarsari Rumpin Bogor. Jurnal Pengabdian Dharma Laksana, 2(2), 142-146.

Seftyono, C., Arumsari, N., Arditama, E., \& Lutfi, M. (2016). Kepemimpinan Desa dan Pengelolaan Sumber Daya Alam Aras Lokal di Tiga Desa Lereng Gunung Ungaran, Jawa Tengah. Otoritas: Jurnal Ilmu Pemerintahan, 6(2), 60-70. 